\title{
The Political Economy of Essence of Money and Recent Development
}

\author{
Kalim Siddiqui ${ }^{1}$ \\ International Critical Thought, vol. 9(1) pp. 1-23
}

\begin{abstract}
This paper attempts to examine the essence of money theory and the mainstream interpretation of money and the financial crisis of 2008. In order to understand the financial crisis, it is important to analyse both classical and Marx's commodity money theory. This study is important because in recent decades the rapid expansion of financial sectors, ballooning of debts and spectacular growth of fictitious capital requires a deep analysis of the capitalist system, and for this there is a need to revisit Marx wisdom, especially his theory of money. He also says that when there is excessive speculation over the future distributions of surplus value then there is a possibility for great instability in the system. Such tendencies were clearly seen during the 2008 financial crisis. Keynes found money's macroeconomic impact, namely uncertainty, which he explains in universal terms. For Marx, the reason for uncertainty is associated with capitalist production decisions, which means capitalists are undertaking production for needs which are unknown to them; they are producing for other individuals not known to them. The study found that a materialist analysis of monetary phenomena is crucial to fully understanding this issue, including the financial crisis of 2008.
\end{abstract}

Key Words: Money, functions, commodity money, Marx money theory, and financial crisis.

JEL classification: B4, E4, B1, B2

\section{Introduction}

This paper attempts to examine the essence of money theory and the mainstream interpretation of money and the financial crisis of 2008. In order to understand the financial crisis, it is important to analyse both classical and Marx's commodity money theory. In recent years there has been more discussions on Marx theory of money (Lapavitsas, 2009; Patnaik, 2009; Brunhoff and Foley, 2007; Foster, 2007), but there is still a need to revisit Marx's money theory in the light of the 2008 financial crisis and the growing role of the financial sector in the globalised economy.

This study is important because in recent decades the rapid expansion of financial sectors, ballooning of debts and spectacular growth of fictitious capital requires a deep analysis of the capitalist system, and for this there is a need to revisit Marx wisdom, especially his theory of money. This study discusses the relationship between abstract social labour and exchange value or monetary expression of labour time. The Marx approach provides us more historical and sociological aspects of the evolution of the theory of money. The importance of Marx theory of money is the emphasis on labour as a commodity and the linking of money to the theory of exploitation, which seems to be important to understand the struggle between labour and capital and also between developing and developed countries (Siddiqui, 2014). The original contribution will be to the understanding of the essence of money in capitalist economies and also to critically examine briefly the 2008 financial crisis.

\footnotetext{
${ }^{1}$ Kalim Siddiqui is a senior lecturer at the Department of Accounting, Finance and Economics, University of Huddersfield, UK. Email: k.u.siddiqui@hud.ac.uk

The author would like to thank to Jamie Morgan and Hugo Radice for helpful ideas and suggestions. The author gratefully acknowledges the three anonymous referees for constructive feedback and insightful comments which contributed significantly to strengthening the article.
} 
The interdependence of logical and historical aspects is crucial in order to understand the classical framework. As Engels notes: "The logical method...is needed nothing but the historical method, only stripped of historical form and diverting chance occurrences. The point where this history begins must also be the starting point of the train of thought, and its further progress will be simply the reflection in abstract and theoretically consistent form, of the historical course. Though the reflection is corrected, it is corrected in accordance with laws provided by the actual historical course, since each factor can be examined at the stage of development where it reaches it full maturity, its classical form" (cited in Green, 1982:64).

Classical economists shifted their focus of inquiry from circulation to the process of production. As Green (1982:72) argues: "Classical economists found the common denominator of exchange value in social labour. The value of commodities was determined by the labour time socially necessary for their production. They applied equally to gold - the universal commodity - which became the direct embodiment of social labour. Ricardo has argued earlier that: "[T] he same general rule which regulates the value of raw produce and manufactured commodities, is applicable also to the metals, their value depending...on the total quantity of labour necessary to obtain the metal, and to bring it to market" (cited in Green, 1982:72).

The study intends to challenge the prevailing view that the quantity theory of money (monetarism) is part of the classical economists' view. The common characteristics of the quantity theory of money are that an increase or decrease in the supply of money, all else being equal, will lead to the same proportion of change in the price level (Rowbotham, 1989; Green, 1982). As Anwar Shaikh (2017: 190) notes: "the Quantity Theory of Money is that it is the total quantity of money, independently of its mixtures of gold coins, deposits or fiat money, which drives the long-run price level... The Quantity Theory of Money has the virtue of simplicity: in Milton Friedman's famous aphorism "inflation is everywhere a monetary phenomenon"" (Shaikh, 2016:190). Monetarist economists assume money alone acts as a medium of circulation. The value of goods depends on their price level and the demand for money needs to be positively linked to the same. In order to analyse the determinants behind the value of money, the mainstream economists' views are based on Walrasian equilibrium, which is unable to offer a theoretically coherent explanation for the functioning of capitalism, including the value of money. It does not clearly explain the preference for money as a form of wealth, but holds exogenously to supply and demand (Grieve, 2017).

This article is organised as follows. Following the introduction to this topic in section 1, section 2 will briefly discuss the money in commodity form. Section 3 analyses the functions of money, whilst section 4 discusses Marx theory of money. Section 5 examinees Keynesian arguments on money. Section 6 analysis money's role in accumulation process and section 7 focusses on hording. Section 8 examines financial crisis, followed by a conclusion which summarises the findings.

Classical economists, for instance, David Ricardo argues that money is to be used as medium of circulation and an excess demand must be matched by an excess supply of all noncommodities. It is different from the Walrasian model where an excess demand for money, and hence excess supply of commodities, is removed through price adjustments alone. Patnaik (2009:89) argues: "Ricardo's theory of value of money, then, was nothing else but an application of his theory of value. Indeed, the essence of commodity money in this perception 
is that the value of money is determined exactly in the same way as the value of any other commodity..."

Ricardo had accepted the monetarist explanation for the short term, but in the long run he believed the value of money was determined exogenously and outside the realm of supply and demand. For mainstream economists, price flexibility facilitates the equalisation of supply and demand, which restores equilibrium prices. They try to convince others of a dream state where individual producer plans are assumed to perfect match society's needs, which is referred to as the general equilibrium (Kaldor, 1982).

Money has value and could be exchanged against other objects. The question arises as to why this useless paper has become so valuable. What determines the value of money?

Monetarist economists argue that the value of money, vis-a-vis commodities, is determined by its supply relative to its demand. Any possibility of over-production in the system is eliminated through the relative price of money vis-a-vis commodities. It is assumed that price movements remove all excess supply of commodities. Critics do not agree with the assumption that in the long term natural tendency towards market equilibrium, and see the possibility of such a crisis occurring and thus lead to overproduction. As Patnaik (2009:6) notes: "The monetarist tradition that the value of money, like the value of any other commodity, is determined by supply and demand... By contrast the main feature of the Marx-Kalecki-Keynes tradition is that the value of money in terms of commodities (whether in the short or in the long run) is determined from outside the realm of supply and demand, by some exogenous consideration. This tradition considers this "exogenous" determination of the value of money to be a central characteristic of capitalism".

The mainstream economists on monetary theory argue that the determination of the value of money can be undertaken in a similar way to which the value of any other commodity is determined, i.e., through supply and demand. But there seems to be a certain inconsistency in such an explanation in the sense that if the supply and demand brings equilibrium to the markets then the value of money will, logically, be zero. This means that not only would money have no value, but people would not be willing to hold it. Therefore, such logic it does not explain why individuals would want to hold money if money in equilibrium tends to have zero value. If the value of money is to be positive then its value must be determined independently of supply and demand (Patnaik, 2009).

Money is produced like any other commodity, but its laws of circulation are distinct to those of other commodities. Marx points out that even money in commodity form is distinct from the other commodities and money is never neutral. He differentiated between money and capital as distinct categories, and further integrated his money theory into the analysis of capitalist production and accumulation. Marx focusses on the capitalist production and creation of surplus value. As he emphasises: "the non-commodity character of money capital helps to shed light on the essential function the money aspects perform in the course of this process. Industrial capitalists' role is to set into motion the production process and to transform it, reproducing it on an expanded role. To do this they must have capital in advance in the form of money. If public expanding is excluded, they obtain this money capital through the creation by banks of means of payment. The circuit of money capital is thus externalized in the circuit of interest bearing capital. The opening of any period of production is 
characterized by the relationship between money capitalists, emblematically embodied by the banks, and industrial capitalists" (cited in Messori, 1997:86).

Marx acknowledges that although labour activities may be due to the effort of individuals, they nevertheless constitute social labour because the products are not intended to be used by the immediate producers. The products are indirectly linked to labour activities. All products are exchanged for money, which means that money is a unifying element of the total labour power of the society. Marx's explanation has two important points, namely that commodity is a form of production, despite being carried out by independent labour, but private ownership of property is used for appropriation and production is for sale (Marx, 1976).

There seems to be division among the mainstream economists over how the Federal Reserve should organise its monetary policy. One section argues that organisation should only be concerned with inflation and try to achieve the target rate of $2 \%$ by decreasing or increasing the supply of money, whilst the others say that the Federal Reserve should also be responsible for, and attempt to influence, employment levels in the economy through increasing or decreasing money supply as a reaction to the economy growing above or below a rate corresponding to a non-inflationary rate of unemployment. Theoretically, mainstream economists' assumptions are based on the fallacious grounds that inflation is caused by an excessive growth of the money supply. Long-term inflationary pressures are due to the fact that the average real-wage rises more rapidly than labour productivity, and to resolve this would be to adopt an income policy. There could also be short-term inflationary pressure due to excessive demand during cyclical upturn (Kaldor, 1982; Eatwell, 1983).

Even during the Gold Standard period, the stability of the international monetary system was not established because of the pound sterling being backed by this precious metal, and thus the pound was 'as good as gold'. The pound was the leading currency in the last quarter of the 19th century, because Britain controlled a vast number of territories as colonies and semicolonies, and Britain as a leading capitalist country, could impose its will on the colonies. These colonies were under British control through the machinations of an oppressive and unequal relationship. After the Second World War, the United States emerged as a leading capitalist country and established a very similar relationship whereby the US dollar was seen being "as good as gold". To continue this, inflation must be kept in check and must not increase at higher levels, which could impact on prices due to pressure from a wage-led inflationary spiral and undermine the confidence of the capitalist wealth holders (Desai and Freeman, 2011).

For the last fifteen years or so, the United States' debts have grown to such a a level that they could pose a threat to its continued status as a capitalist leader. In fact, a similar situation was seen earlier when Britain was a leading power during the 1860-1913, which was a period of expansion of capitalism and emergence as global capitalist relations. However, despite growing military expenditures, Britain did not become indebted in the process, as it should have been. In fact, the opposite happened, and Britain not only did not become indebted, but at same time also emerged as the world's largest creditor nation. What we see in the United States' case today is just the opposite. The difference is due to Britain then having colonies and semi-colonies offered markets for its products, which could not be sold in the competitive markets of Europe and North America. The other important reason was that newly industrialising countries had increasing demands for raw materials and they imported from Britain's colonies and, as a result, these British colonies had export surplus. This 
certainly helped Britain to balance its current account deficit with the newly industrialising nations in the last quarter of the 19th century. The United States do not possess such colonies and the present international situation is quite different (Patnaik, 2009).

\section{Money in Commodity Form}

The commodity view of money explains that money evolved from the market which is linked with the barter system. In this process, a commodity was accepted as a medium of exchange to solve the difficulties of finding suitable mutual exchanges. A portable means, which was also durable such as silver or gold, was seen as most suitable. The precious metals such as silver and gold were viewed as an ideal material for money, which was due to interesting physical characteristics of these materials such as durability and divisibility. In the case of commodity money, gold could be acceptable to society because it was already acceptable and considered valuable (Messori, 1997). Marx argues that money is a special commodity with universally accepted purchasing power such as gold, mainly due to being historically accepted and validated by the state (Marx, 1976).

In the case of barter, one commodity such as grain is exchanged directly for many other commodities. For instance, grain was exchanged for salt, meat and others. The quantitative worth of grain was expressed in specific quantities of different commodities. Under such a system grain, for example, has many different exchange ratios with different commodities, which were accepted by the relevant societies. For example, tobacco was used as money in colonial Virginia, Maryland and North Carolina. Tobacco was also used as generalised form of value including payment for purchases and for paying fines and taxes. A number of items such as tobacco, corn, wheat, tallow, leather and beaver skins served monetary functions in Maryland and were recognised as legal tender in 1631. As Peacock (2017:1481) notes: "In Virginia which like Maryland, relied on tobacco cultivation for its economic livelihood, tobacco was used in market exchange and payment of taxes... By legislative act of 1619, Virginia designated tobacco a means of payment."

Moreover, for hundreds of years, Cowries Shells were used as a means of payment in India, China, Arab countries and in West Africa. As Quiggin argues, Cowries had been in circulation as a means of payment by traders from "India, China, eastward to the Pacific Islands... across and encircling Africa to the West Coast... and penetrating into the New World, before and even after the general use of gold and silver in some of these regions" (cited in Shaikh, 2016:170-171). In fact, Cowry Shells could satisfy most of the characteristics of money such as being portable, countable, recognisable and difficult to counterfeit.

Kopytoff advocates that monetary analysis should be based on anthropological explanation and stresses that money alone does not say much, but only takes on an accepted value with a set of rules associated with general social organisation and social norms. Of course, money in a single commodity division of labour is not the same as money in a commodity division of labour in a society dominated by wage production. Kopytoff argues that commodity and exchange are generally used in all societies (Cartelier, 2007). He tries to explain what makes a thing a commodity and, when exchanged, what they have in common: "The perfect commodity would be one that is exchangeable with anything and everything else, as the perfect commoditized would be one in which everything is exchangeable or for sale. By the 
same token, the perfectly de-commoditized world would be one in which everything is singular, unique and un-exchangeable" (cited in Cartelier, 2007:224).

In 1789, during the revolution in France, the revolutionary committee adopted paper money, as they could not draw on precious metals, such as gold and silver as they were either hidden or sent abroad. As silver and gold were not available, tax collections were not feasible and borrowing options were limited under such circumstances. However, during the revolution, huge areas of land were confiscated from the Church and the Crown and, therefore, landbased papers were issued, which were backed by the promise of redemption through funds derived from planned sales of Crown and Church lands (Shaikh, 2016).

Commodity money could take the form of silver, gold, seashells or whatever else community accepts. An interesting narration has been presented by Searle (2017:1455): "In the beginning, there is only commodity money such as gold and silver, but it is inconvenient to carry gold and silver around, so one leaves it with a man who sits on a bench called bank. This man is called banker. In return for the gold and silver, the man gives you set of documents that constitute promises to pay the bearer in the gold and silver in the bank. This is much more convenient and safe than carrying actual pieces of metal. But as long as the banker honours the contracts, the contracts are as good as gold. The contracts now replace the commodity as money. Another form of flexibility, and a form of deception that is easy and really inevitable, is to issue more contracts than the actual amount of gold and silver in the bank. As long as everybody does not run to the bank all at once, the contracts function just fine."

In the early 17th century, the goldsmiths in London and other big English towns issued receipts certifying the deposit of a specific sum of money which could only be redeemed by an indicated person. However, these receipts did not function as a means of payment. In the second half of the 17th century, rather than mentioning the name of original depositor word was replaced by "bearer" so that the deposit receipt could act as a means of payment for whoever held it. Furthermore, in 1704, such practice was validated by written statute and original deposit receipts were being accepted as money tokens. By the early 18th century, the practice of accepting deposits and receipts was called "bank notes" and was not limited to English towns but had also spread to rural areas. Paper tokens were also used in North American colonies in Massachusetts in 1690. The people opposed taxation without representation, and then paper money was accepted by the colonial administration to declare legal tender for taxes by 1751. The British Parliament ended such monetary practices in its colonies (Shaikh, 2016).

In the past, the community used commodity money for the exchange of products. However, it was inconvenient to carry commodities such as gold, silver, corn, and wheat around. The banker came to act as a middle man during the exchange process and, in return for gold and silver, the banker provided a set of documents that constituted a promise to pay the bearer in gold from the bank. This contract replaced the commodities with paper money. This is a form of deception; but this is fine as long as the bank kept the promise: "This money has become fiat money, not because this paper is really money, but the authority had said it is money. As ... 'The Bank of England promises to pay bearer on demand twenty pound', but the promises are meaningless because the only thing they can pay with is what you already have. In the USA, this step is known as 'going off the gold standard' and it occurred in two stages: first, in 1933 when the government announced that they would not redeem paper currency in gold 
to individual citizens, and second, in 1971 when the government announced that they would not provide other governments with gold in return for US dollars." (Searle, 2017:1455).

\section{The Definition and Functions of Money}

The function of money most commonly described as: i) commodity money: the use of commodity as money. The commodity may be gold, silver, corn, tobacco, seashells and so on, whatever is accepted by the community in question. In simple form, it is like barter. Not all exchange requires money. For instance, if a purchaser gives an amount of corn for a pair of shoes, in this case money has not changed hands. ii) Contract money, here the money is used as a contract on the promise that the money, in this case in paper form, promised has been made to pay the bearer a particular amount on demand. It is illustrated on the pound note. This is common form of deception in this case about money (Searle, 2017).

Adam Smith explained that the process of competition in a market means the price of a commodity is just sufficient to pay for labour and land and the stock used in its production at their natural rates, being sold at its natural price. This is what he called central price, around which the prices of all commodities gravitate (Green, 1982). For Smith: "A deviation of market form natural price simply indicated an excessive or deficient 'effectual demand' in relation to the available quantity of a particular commodity. This deviation, however, was self-correcting, for the supply response "naturally suits itself to the effectual demand" (cited in Green, 1982:61). This does not mean that natural prices are fixed by the interaction of supply and demand.

An Adam Smith view on money was an adding-up theory of natural price, which for any commodity was calculated by adding up sum at natural rates of wages, rent and profit. He further said that when the price of corn increases, so it affects prices of all other commodities. It also means that if corn prices rise in terms of money then wage rates decrease in order to ensure that the rate of wages in real terms remains unchanged. Adam Smith characterised the Price Revolution as an increase in natural prices due to the greater fertility of the American mines and as a result less labour content was required for each unit of the money commodity. As Smith stated, "the discovery of the abundant mines of America reduced, in the sixteenth century, the value of gold and silver in Europe to about a third of what it had been before" (cited in Green, 1982:73).

To answer the question of why money is accepted as money, we have to understand history and civilisation. Money performs crucial functions such as acting as a medium of exchange, store value and as a measure of value (Searle, 2017). Lawson (2016) presents four functions of money - medium of exchange, means of payments, unit of accounts, and store of value. He also argues that money had been issued from a process of 'social positioning'. Before being positioned as money, it must have a store value and be trustworthy. While explaining the concept of what is the value of money, Lawson describes money as payment task is discharging the obligation of debt. Money as a medium of exchange includes it functions to meet an obligation to pay. He says the value of money as a means of payment necessarily serves as a medium of exchange. He argues, "a community-wide system of value measurement or accounting is a historical pre-condition of a valuable item becoming positioned as a general form of value and means of payment" (Lawson, 2016:969). Also, the 
system of accounting is associated with the measurement of value; otherwise there is no sense of value itself. (Lawson, 2016:970).

Money is also an indication of social relations, where money is a promise to pay, which is an obligation, and therefore is a debt. The debt is a social relation between parties. If money is a debt, therefore debt is a social relation. Similarly, Peacock (2017:1475) explains: "a unit of account in Lawson's terms, namely, as a historical precondition of a monetary system in which credits and debts are created and annulled via payment. However, Keynes's categorisation...states that the unit of account function is logically anterior to money's other functions and to market exchange".

Marx attempted to differentiate between convertible and inconvertible money. If money is convertible, then it is carrying out its imminent function. The difference is important when gold is an effective medium of pricing because one can acquire gold as a medium of safety and convertible money represents a fixed amount of gold. He assumed that gold is the effective medium of pricing. The long-term price level is the product of the relative price of the average commodity, vis-à-vis gold and the absolute token price of gold, where the value of the latter is determined by the monetary regime in operation. For Marx, in the case of convertible tokens the long-term price level is independent of the quantity of money. In the long-run, the price level of regular commodities is the outcome of two factors, namely the relative price of these commodities vis-à-vis gold determined by structural factors and competition, and the money price of gold determined by monetary and macroeconomic factors (Marx, 1976; 1978).

The development and spread of banks provided "private hoards" and the rich an opportunity to keep their money as loanable capital and to increasingly rely on the financial system. Their deposits can be loaned out by the banks. In fact, the rising profits and increased revenues derived from sources such as ground rent and the incomes of higher forms of salaried workers lead to the concentration of wealth; Marx commented: "the credit system must be further developed, which means an increase in number of bankers, money lenders, financiers, etc." (Marx, 1981:643) Marx further emphasised that the banks are seen not only as middlemen between depositors and borrowers, but also that the bank creates money and as a result extends credit beyond the original amount deposited. This is what Marx called the proliferation of "fictitious capital" i.e., a tradable title, which claims a future flow of income and surplus. Credit money was undeveloped in the second half of the 19th century when Marx was writing Capital, but still he emphasised that the credit system is simply a form of money economy. For him, credit money was born directly from the function of money as a means of payment. Marx explains that exchange value is divided into two independent acts of sale and purchase and exchange takes place for the sake of exchange, not for consumption. The credit system is important for the expansion of capitalism and credit accelerates to expand production and development of technology and research. The credit system also accelerates contradictions and crisis. The main aim of the capitalist is to earn profit. The credit system could lead to overproduction and speculation activities (Marx, 1981:752).

A person with money is able to buy goods and services, which means money gives him/her more power than another person who does not have money. What does a 20 pound note tells us? It has a status symbol, as it indicates that that the money can perform specific tasks by the virtue of the collective acceptance of that status. For money to function in its task, it has to have collective acceptance. It was not practical for people to carry commodities around, so in 
order to get other products, bankers entered into the picture. They issued certificates that were redeemable in gold or silver. The contract had the status function that the bankers pay the bearer on demand so much in gold or silver. As long as the contract was met, the bearer was satisfied. However, if all parties want their contract to be met at once, then the banker will be bankrupt. How this does not happen? This is another deception, which occurs when more contracts are issued than there is money held by the contract issuer sufficient to redeem all contracts at the same time. On this issue, the government sets a reserve ratio, where legislation ensures that a certain percentage of the loans must be kept by the bank. Each individual bank creates credit when they grant new loans. In fact, these banks provide financing through new money creation. This is the magic of double-entry accounting. The loan is an asset and deposits in the account of the borrower represent a liability to the bank (Peacock, 2017).

Galbraith (1975) argues that banks are very important source of the creation of money and unravels the deep mystery: "Modern fractional reserve banking evolved out of the operations like those of private English goldsmiths or the public Bank of Amsterdam. As noted these guardian banks initially issued receipts for safekeeping, and after some time these receipts themselves began to be used to make payments. The receipts turned into bank notes as they began to function as medium of circulation. But not of course, as universal equivalent, in which the notes still had to be redeemed" (Galbraith, 1975:19). This simply means that when a loan is given, new money is being created. Similar points were emphasised by Victoria Chick: "money confers on those with authority to issue new money the power to pre-empt resources" (Chick, 1992:141).

\section{Marx's Theory of Money}

Marx built on the works of the classical economists Adam Smith and David Ricardo, particularly on the labour theory of value, but he radically transformed it. Marx (1976) discussed value in Capital volume 1 as having three aspects: a substance (i.e., abstract labour), a quantity (i.e., socially necessary labour time), and a necessary form of appearance (i.e., exchange value). Under capitalism, the exchange value becomes very important and under such circumstances, money provides its owner a claim on part of the total labour time of society. Labour itself is not advanced in the production, but rather money in the form of abstract labour. In fact, individual labour (i.e., concrete labour) produces a commodity which has utility for others as use value. The abstract labour is a portion of total labour exhibited in the money value of output (Marx, 1976).

The value of a commodity is an expression of the abstract element of the social and necessary labour expanded in its production, where the value is expressed in the form of money. The exchange value of a commodity, according to Marx, is a social element which is in the commodity and is indicated by the labour expanded in its production (Foley, 1986). The commodities are similar with each other in the sense that they all contain the same substance, i.e., value. Marx emphasised how this value substance must find some form of social expression. He saw a number of reasons why exchanges, in reality, will not exactly reflect the quantitative relation between the values of commodities exchanged. In the real world, the value of a commodity exchanged will be sold either above or below its true value (Foley, 1986). 
The differences between the price of a commodity and its value are due to the relations between buyers and sellers in the markets where the commodities are being exchanged. In fact, as Marx stated, the ratios at which commodities are exchanged depend on the bargaining power of the buyers and sellers. The value of the commodity in money form is inherent in the commodity relations. He noted that a commodity which has become a general equivalent, such as gold, could be termed a 'money commodity', and as a monetary unit had a standard price. For instance, a fixed amount of gold with which a commodity is being exchanged depends on the relationship between the labour-time contained in each. Due to changes in production conditions and improvements in technology in both the production of gold and the commodity in question, the labour time as inputs into the production of both is constantly changing (Foley, 1986).

For Marx, the prices of commodities are determined by their conditions of production. Marx also highlighted that the commodity form of production is a social form of production because this production takes place in an extensive social division of labour. Each worker depends on each other to produce, which depends on vast cooperation and net workings. On the other hand, when the commodities are being exchanged then it creates an illusion of privacy and becomes very subjective and largely depends on a matter of a few individuals and other people. This, Marx called fetishism of commodities (Marx, 1976).

Abstract labour, which a commodity commands, does not result only due to production but also the articulation between production and exchange. As Messori (1997:58) notes: "Abstract labour, the commodity, and the value are not the result of production alone but of the articulation between production and exchange. The process of production creates potential value: the sphere of circulation creates effective value via the realization of potential value (prices in money terms) and the associated transformation of the product of labour into a commodity. Marx's theory of value therefore rests on the intrinsic link between abstract labour and money". Foley (1986) argues that monetary expression of value in Marx's theoretical value concept is based on abstract labour, which simply means abstract labour to be transformed into money form. The gold, as a money commodity under capitalism, becomes commodity money and acquires 'general social validity'. Marx discusses the value of a commodity in his analysis by identifying money as a commodity which then moves through the exchange between commodities, where he argues: "Gold in now money with reference to all other commodities only because it was previously, with reference to them, a simple commodity. Like all other commodities, it also performed as an equivalent -either as a single equivalent in isolated acts of exchange or as a particular equivalent along with other commodity equivalents" (cited in Messori, 1997:51-52).

There is a dual character to commodities as they represent both value and use value. The use values are not always in themselves grounded as they represent the "material content" in the form of wealth. Under capitalism, this assumes the historical character of the "material embodiment of exchange value". This also means for those who possess products due to ownership of production, use values to assert themselves by satisfying needs of purchasers with the help of exchange. The exchange of commodities is the process in which the output is sold. On the simple form of commodity money, Marx begins with money: although it is produced like any other commodity, its laws of circulation are very different. He analysed commodity money: "how and why and by what means a commodity becomes money" (cited in Vasudevan, 2017: 71). Marx shows that money's contradiction as having a used value and 
exchange value is resolved as the exchange value of the commodity becomes a separate money form, which is different from other commodities, and that prices are expressed in exchange values. Under such a situation, producers become more dependent on exchange value because this becomes the most important form of value (Vasudevan, 2017).

Karl Marx analysed the social effects of money. He linked these to the labour theory of value with his well-known expression C-M-C (commodity-money-commodity), where simple commodity circulation with wage can be related as follows: M-C-M* (money-commoditymoney). (Arnon, 1984) Marx emphasises that with money (M), a commodity (C) is purchased and handed over for money (M), which is different from a credit transaction where both transactions are separated in time. In the latter, money functions as a means of payment; while in the former it functions as means of purchase. According to him, this surplus value forms the basis of profit, interest and rent. In the equation put forward by Marx, this is: M-C$M^{*}$, where $M^{*}>M$. The circuit of money requires a logic of sequential determination as $M$ cannot be determined at the same time as $\mathrm{M}^{*}$, meaning the capitalist must advance money before it can be recovered. The prime focus of capitalist production is to make profit, i.e., an expectation to make more money than initially invested (Marx, 1976; Shaikh, 2016).

The Marx theory of money is interrelated with his theory of value. He explains money as being a form of value, as derived from the theory of the commodity, which is inseparable from use-value and exchange-value. He argued how a commodity is produced, such as gold, which society has accepted has a general time equivalent and functions as a measure of value for all other commodities (Arnon, 1984). Marx adds skilled labour time with a "multiple" of simple unskilled labour time and then how this multiple is determined. Marx notes: "The value of labour power is determined, as in the case of every other commodity, by the labour time necessary for its production, and consequently also the reproduction of this special article... the peculiar nature of labour-power as a commodity is, that its use value does not, on the conclusion of the contract between the buyer and the seller, immediately pass into the hands of the former" (Marx, 1976:170).

Marx rejected Say's law, where every sale is a purchase and every purchase is a sale and argued that the circuit of commodity circulation breaks where buyers outnumber sales of one commodity while at the same time for all other commodities the number of sellers is greater than that of buyers, meaning that they are unable to sell. Contrary to the quantity theory of money that prices are given, Marx emphasises that prices do not depend on the quantity of money in circulation. The quantity of money in circulation is determined by the sum of prices of commodities to be realised and the speed with which currency circulates; this could increase or decrease along with prices. Marx criticised Say's law in that 'supply creates its own demand', by arguing that hoarding creates a situation in which aggregate demand will not be equal to aggregate supply (Marx, 1976).

For Marx, money as a means of payment shows a contradiction. As long as payments are in balance, the circulation will be carried out by money, when the payment is not in balance, then in order to make payment, money enters "universal equivalent" and failure to meet the obligation could have negative effects. A monetary crisis can erupt when the chain of payments is disrupted (Arnon, 1984).

When Marx was writing Capital, monetary debates were divided along the currency and banking schools of thought. The currency school argued that from the quantity of money in 
circulation to prices, money supply was exogenously determined. They also favoured strict control over the issue of paper notes and recommended rules to separate money creation from banks. The banking school viewed the supply of money as being endogenously determined, and should adopt to demand and price levels. They also argued that rules of separation of money issuance from banks would be unhelpful. However, the quantity theory of money and currency school only emphasise the function of money in hoarding and as a means of payment.

The mainstream economists on monetary theory argue that the determination of the value of money can be undertaken in a similar way to which the value of any other commodity is determined, i.e., through supply and demand. But there seems to be a certain inconsistency in such an explanation in the sense that if the supply and demand brings equilibrium to the markets then the value of money will, logically, be zero. This means that not only would money have no value, but people would not be willing to hold it. Therefore, such logic it does not explain why individuals would want to hold money if money in equilibrium tends to have zero value. If the value of money is to be positive then its value must be determined independently of supply and demand (Patnaik, 2009).

The critiques on Marx's application of general principle was on the question of skilled labour by economists such as Bohm-Bawerk, and later by Paul Samuelson, who incorrectly assumed that Marx sought to reduce skilled labour to simple labour through the exchange process itself, using relative wages as the appreciate weighting scheme (Meek, 1973). "[Marx] critical corrections concerning the concept of labour can be summarized in the following statement: the labour that produces value is abstract rather than concrete, simple rather than compound, social rather than private, and necessary rather than wasted .... whenever we see someone working we see them doing some specific task as part of some specific production process. We see someone spinning thread or weaving cloth or punching data or smelting iron... Marx argues, then, that in a commodity-producing society it is labour in general, or abstract labour, that produces value... Marx acknowledges, as Ricardo does that individuals differ in their capacity to produce value... or the result of different persons having reached different stages of development of their productive powers because of different life experiences is not particular important in this context." (Cited in Foley, 1986:15-16)

\section{Keynesian Arguments on Money}

In the neoclassical model (i.e., Menger-Jevons-Walras) all prices, including factors of production prices, are determined by demand and supply, while in Ricardo-Sraffa traditional factors of production's incomes and wages are socially (independently) determined and a price system is built on that basis. The relative prices between commodities in equilibrium are independent of demand, but largely dependent on the conditions of production. Also, Menger-Jevons-Walras model assumed that aggregate demand does not create a constraint on production and they support Say's law of "Supply creates its own demand", while Keynes disagrees with this proposition, and begins with the acknowledgement that capitalism has a demand constraint problem (Robinson, 1956).

Keynes' model focuses largely on three key issues: namely unemployment, quantity of money, and rate of interest. However, Keynes gives only a limited discussion on international economy. Keynes presented his theory to save capitalism. Keynes does not incorporate 
history into his analysis; further, he does not say anything about the state. In fact, a state has the capacity to manipulate money supply (Keynes, 1964).

In the Keynesian model, the supply of money and the rate of interest are given. The level of liquidity preference determines the proportion of money active or hoarded in society (Keynes, 1964). It is assumed that rate of interest determines the volume of investment and thereby volume of national income. All factors are present here with the exception of levels of general prices, which are supposed to be determined by the quantity theory of money, i.e., the ratio between the real national income and quantity of money in circulation (Robinson, 1956). Keynes argued that money was an independent of market forces and can have a severe impact on the productive economy if the money system malfunctions (Rowthorn, 1984). Markets alone are not necessarily efficient, money might not circulate, and people may be reluctant to spend. Under such circumstances, government intervention may be required to maintain the circulation of money, i.e., liquidity (Chick, 1992).

Kalecki argues that effective demand determines the level of economic activity, the fluctuations in investment, the importance of degree of monopoly is in setting the price-costmargin, and also that it influences the distribution of income between wages and profits (Sawyer, 2001). He refuted the mainstream claim that inflation can be identified with the existence of a large budget deficit. "[He argued] budget deficits do not necessarily involve inflation and that a balanced budget is not a safeguard against inflation... Any deficit generates enough savings to finance itself. However, if the deficit is financed by short-term Treasury bills sold to the banks, the budget deficit is said to be financed by "credit creation" not by "genuine savings", and it is this way of government borrowing which is held responsible for the evils of inflation" (cited Sawyer, 2001:250-51).

Keynes suggested that the value of money, vis-à-vis the world of commodities, was fixed through the fixing of the value of money, vis-à-vis commodity. The stability of money is also linked to a set of social relations. The capitalist economies are associated within an overall international monetary system which is based on imposed unequal relations. This becomes important in order to run the capitalist system and that the stability of the value of money can be associated with the stability of the international monetary system and, through the persistence of unequal social relations, manage to build confidence of the wealth holders in the leading economy's currency as a stable medium of holding wealth (Patnaik, 2009; Robinson, 1956).

Patnaik (2009) argues that it is not commodity in general which serves at present as international money, nor even gold, but oil. He further argues that the value of money in any national system is embedded in the international economy. Then, what can serve the function of international money is very similar to Keynes views, that it will be the commodity whose return exceeds its carrying cost by more than any other commodity. In this sense, gold seems to be suitable for this role within the global system because of the low costs of carrying it. This seems close to the neoclassical position that all international transactions are implicitly barter transactions because debts are paid through the transfer of goods, and gold was chosen because of its physical properties.

However, the orthodox economists emphasised that price flexibility will ensure full employment levels in an economy and unemployment occurs only as temporary phenomenon due to price stickiness and as a result the slowness of the market mechanism to perform its 
equilibrating role. The orthodox view was that a deficiency of demand related to productive capacity will not occur and any short-term disequilibrium will be restored to equilibrium via the self-correcting market mechanism. The orthodox economists did not see any possibility of deficiency of demand. However, some mainstream economists, while accepting the imbalances, attributed this to the imperfect working of the price mechanism. As Grieve (217:483) notes: "[A]n increase or decrease in spending, would depend on the degree of money wage and price flexibility. If, with full flexibility, all money values responded immediately and proportionately to the monetary change, the price level would alter without any impact on output and employment. But if, as was considered more likely, commodity prices altered more quickly than money wages, real wages would be affected, resulting in changes in employment and output... The cyclical unemployment associated with such a sequence of events could be classified as "frictional" - attributable to slow adjustment of the money... wage rate..."

Keynes argues that investment decisions are made under conditions of uncertainty. Keynes also emphasised that investors may prefer to maintain liquidity so that they can manoeuvre, rather than committing to something they are uncertain about. His liquidity preference removed the rate of interest from its equilibrating role. A general deflation of money wages and prices were not considered by Keynes as a mechanism towards economic recovery (Grieve, 2017). This point was further explained by Morishima (1977) by rejecting a Walrasian-type macroeconomic model that price flexibility may not guarantee full employment. "Keynes ... opposed this [classical] view, he believed that that the neoclassical full-employment, full capacity equilibrium does not exist, because investment is determined independently of savings and therefore, even if the wage is perfectly flexible, the economy cannot settle down at any point because of the over determinacy" (cited in Grieve, 2017:492). The economic policy question has divided the economists between monetarists and Keynesian economists over monetary policy as to whether increased levels of employment will create excessive demand for labour, which will generate a wage-price spiral of inflation (Siddiqui, 2015a).

\section{Money in Accumulation Process}

Marx, in Capital volume II (1978), starts with an analysis of capitalist accumulation in a simple form of circulation which developed into a capitalist form of circulation, where capitalist social relations based on wage labour are established. In the circuit of capitalist production, a sum of money can be converted into commodities with the help of wage labour and the ownership of means of production. This process also means transformation of money capital into productive capital, which can produce surplus value. In such a situation, money enters not only just as a means of payment but also as a form of capital. As Vasudevan (2017:74) observes: "The transformation of money capital into productive capital interrupts the circuit, as productive capital is transformed into a new inventory of commodities in the course of the capitalist production process, where surplus value is created and appropriated through the wage relation. The money, between the capitalist who buys labour power and the worker who sells, is embedded in production and production relations... As commodity capital, capital must now re-enter the sphere of circulation as the capitalist realises the value of this capital only by selling the inventory of commodities... The circuit is complete as capital once again assumes the form of money, but it now expresses both the outcome of capitalist social relations and also the point of its return". 
Money capital, productive capital and commodity capital have the different functions that capital has assumed in the course of the circuit of capital. The money also begins to appear as independent form of money, which builds the illusion that money breeds money without taking into account the intervening phase of how capital is used in production activities. However, when the circuit is not functioning correctly, then labour and capital are not in use, i.e., they are idle. The whole circuit stops and results in lack of demand. This also means investment profit is reduced below minimum expectations.

Capitalist accumulation requires an increasing quantity of money, not only because the GNP (Gross National Product) is rising but also because of the transformation of saving into investment may take place, which may constantly need to be added into the system before the gross national product has risen. New investment will create new avenues for expanding output. For investment, investors need to possess a certain amount of money (Campbell, 1997).

Marx emphasised the accumulation of value, that is, socially necessary labour time is embodied in retained capital. "[This] is an important difference, since an economy can stagnate in value terms even though it is apparently growing in "real," that is, use-value, terms. And second, insofar as Marx distinguishes production from finance, his primary distinction is between activities that produce value and those that do not-that is between productive and unproductive labour. The latter is not exhausted by finance: for example, a production organized by the state also does not produce value, though it does produce usevalue. This is why very large-scale state investment restored the US economy during the Second World War... Financial activity however produces neither use-value nor value and is entirely parasitic... Even former banker and UK Financial Services Authority Chairman, Adair Turner, recognised some of the truth of this when he said much banking activity has been "socially useless"... If the banks created value, the enormous state support they have received so far into the crisis should have resolved it" (Desai and Freeman, 2011:40). Marx made clear a distinction between activities that produce value and those that merely circulate it. The money creation process has become as simple as the former Director of the Bank of England, Josiah Stamp, expressed about the moral issue: "Banking was conceived in iniquity and was born in sin. The bankers own the earth. Take it away from them, but leave them the power to create money, and with the flick of the pen they will create enough deposits to buy it back again" (cited in Rowbotham, 1998:35).

Keynes, like Marx, saw that the capital accumulation process involves ownership of real assets and holding the paper claims to those real assets, while mainstream economists assume that productive and financial investments are tied together, and it is further assumed that savers will buy financial claims from entrepreneurs who will invest in acquiring expanding production. But, historically, this has been proven wrong. There seems to be no direct connection between productive investment and the accumulation of financial assets. Keynes also saw the important role of money and linked instability in the financial markets to fluctuations in investment decisions which, according to him, is the chief cause of involuntary unemployment (Keynes, 1964).

\section{Hoarding}

Hoarding is the withdrawal of money from circulation, which breaks circulation. With the process of hoarding, money assumes a special function and enters the circulation process not 
as a medium of circulation but as a means of payment. Under such situations, the relation between sellers and buyers is transformed into that of creditor and debtor. The borrowers will be under compulsion to sell their assets or labour power in order to repay debt obligations (Marx, 1976).

During a crisis, money is hoarded due to pessimism among investors and entrepreneurs, which can lead to unsold commodities and involuntary unemployment. Crises break the circuit, which Keynes defined as a result of a rise in liquidity preference and with firms being reluctant to invest (Keynes, 1964). Marx emphasised that hoarding is the result of the separation between sale and purchase, which is due to other causes. Circulation is broken due to fall in output prices for a number of reasons including production being unprofitable, which encourages hoarding. The breakdown in circulation is caused by a fall in output prices, as this could lead to hoarding. Hoarding could be the result of a passive consequence of the breakdown of circulation, as production becomes unprofitable. For Keynes, as Marx emphasised earlier, the principal reason as to why capitalist production is anarchistic and has a fundamental contradiction is due to income distribution. Real wages were kept down to raise profits, which could unbalance the level of aggregate demand required to buy the total social product (Campbell, 1997).

For Keynes, aggregate demand is associated with the monetary problem and low profit expectations could be the influence behind hoarding, which creates unemployment. As Campbell comments, "The theory of money as universal equivalent explains how these apparently mutually exclusive features could coexist in one system. In its absence, either one aspect or the other must be considered dominant. Hence, economics divides into two camps, the one holding fast to equilibrium ("rational expectations" or true prophecies, the long run, and logical time), the other, to disequilibrium and crises (expectations, the short run, and the real time). From Marx's perspective, proportional production (general equilibrium) is an accident...[H]e suggests the economy tolerates some degree of incoherence (disequilibrium) and respond to intolerable levels of incoherence, not by tending towards coherence (equilibrium), but by collapse in crises" (Campbell, 1997:74).

By placing money in the credit system, hoarders can claim a share of surplus value instead of being "idle". This makes the individual capitalists interdependent by putting money into a common fund. Marx stresses that interruptions in the reproduction of capital are being turned into crises. With the credit system, the surplus value is turned into debt. There is no realisation problem if the rise of debt corresponds to the expansion of value of the output because the anticipated values are being realised. If not, meaning that debts rise more that the value of the output, then the credit system finds itself with a realisation problem. This simply means the reproduction of capital is in difficulty, as debt commitments have exceeded sales expectations. When this becomes known, all debts are discredited which would result in periodic cancelation of debts; such a situation was referred to be Marx as the collapse of the credit system (Marx, 1976; also 1981).

\section{Financial Crisis}

Minsky (1986) observed if a business finds it difficult to repay its debts and borrowers becomes vulnerable, and then cash outflow exceeds cash inflows, this could lead to the eruption of a crisis. Then businesses have to resort to increased borrowing merely to repay their debt obligations. Such a situation can precipitate bankruptcy, financial crisis and 
economic instability. As Minsky argues that the "financial structure is the cause of both the adoptability and the instability of capitalism" (Minsky, 1986: 175). Minsky postulates that a key factor in provoking the above is a crisis of accumulation of the debt by the nongovernment sector. He narrated three types of specific debts which could contribute to the accumulation of insolvent debt, namely by: speculative, hedge and Ponzi borrowers. Minsky's model emphasises that capitalism is inherently unstable and has tendencies towards self-destructiveness.

Due to deregulation and capital liberalisation, the world economy has become more vulnerable to financial crisis, and it is clear there could be also be a number of implications for developing economies in this regard. Unlike the colonial period where capital was largely restricted to mines, plantations and infrastructures, today the re-allocation of industries and capital is from the advanced to developing countries in order to take advantage of the low wages prevalent in the latter under the control of financial capital and businesses from the former. During the 'golden age' of capitalism in the industrialised countries, state intervention through Keynesian policies of demand management was the key hallmark of that period. Also, the state was able to finance the developmental projects that directly benefitted poor people, including petty production. At present, adopting such possibilities would be contrary to the interests of the corporate financial oligarchy, and the economies of the developing countries are closely integrated with international finance capital. As a result, developing countries have been forced to implement 'fiscal responsibility' and to withdraw state subsidies (Patnaik, 2009).

Here, this discursive feature of money has been explained by De Bolla: "[Between 1715 and $1770 \ldots$. a rather strange mechanism began to work in which England maintained its attractiveness to foreign investors by waging war with France - the reason for the debt in the first place - both in the literal sense, in the commitment of arms and troops, and in a more indirect sense, and in the management of interest rates... [I]n light of the fact that peace time interest rates were habitually lower than those during a period of national aggression.. the was situation was dangerously close to an infinite chain of cause and effect, in which the termination of war could possibly lead to the most damaging defeat for England... the Bank [of England] stabilizes its institutional power functions during the debt crisis, still less haphazard that the increase in paper money not only accompanies the increase in its institutional power, but also the increase in its discursive power" (De Bolla, 1989:107-108).

The rapid growth of finance was having detrimental effects on the real economy, as Magdoff and Sweezy noted: "Does the casino society in fact channel far too much talent and energy into financial shell games. ... There is no reason whatever to assume that if you could deflate the financial structure, the talent and energy now employed there would move into productive pursuits. They would simply become unemployed and add to the country's already huge reservoir of idle human and material resources. ... What growth the economy has experienced in recent years, apart from that attributable to an unprecedented peacetime military build-up, has been almost entirely due to the financial explosion" (cited in Foster, 2007).

In their view, capitalism was undergoing a transformation, represented by the complex, developing relationship that had formed between stagnation and financialization. A decade later, Sweezy emphasised: "I said that this financial superstructure has been the creation of the last two decades. This means that its emergence was roughly contemporaneous with the 
return of stagnation in the 1970s. But doesn't this fly in the face of all previous experience? Traditionally financial expansion has gone hand-in-hand with prosperity in the real economy. Is it really possible that this is no longer true, that now in the late twentieth century the opposite is more nearly the case: in other words, that now financial expansion feeds not on a healthy real economy but on a stagnant one?" (cited in Foster, 2007)

It seems that financialisation has ended in a shift in the gravity of economic activity from production to finance. This financialisation arises as a counter to the stagnation and accumulation tendency of capitalism. With the growth of financialisation in the economies of industrialised countries, Sweezy (1994) warned: "Financial capital once cut loose from its original role as a modest helper of a real economy of production to meet human needs, inevitably becomes speculative capital geared solely to its own expansion. In earlier times noone ever dreamed that speculative capital, a phenomenon as old as capitalism itself, could grow to dominate a national economy, let alone the whole world. But it has". Another study by Krippner (2005) argues: "[T] he growing weight of finance in the American economy as "financialisation," and brings forward evidence to support the view that there has been financialisation in the U.S, post-war economy. This does not preclude that there has been financialisation in other periods and in other countries...financialisation as a pattern of accumulation in which profits accrue primarily through financial channels rather than through trade and commodity production" (cited in Sawyer, 2014:6).

The current period of expansion of the financial sector is backed by neoliberalism (Siddiqui, 2012), which has specific characteristics and needs to be analysed in terms of the causes and implications of such policies. Ben Fine (2011) described the current era of financialisation as having the following characteristics: large-scale proliferation of the financial market; this is closely associated with the deregulation of financial sectors, though it has also been linked with the creation of range of financial institutions; the increased domination of finance over the industry; and the increased penetration of finance into a widening range of social and economic reproduction sectors, such as education, health, housing and pension. As Sawyer (2014:9) warns: "securitization, which went alongside banks and other financial institutions, is shifting from an "originate and retain" model to an "originate and distribute" model. This shift has had implications for the operation of monetary policy and its objective, and is related to the rapid growth of "fictional finance," as assets and liabilities grew rapidly relative to gross domestic product (GDP) and measures of productive capital, as well as the fragility of the financial system. The pace of deregulation speeded up, and there were major shifts from public and mutual ownership to private ownership".

James Tobin argues the following in reference to the efficiency of the financial system: "I suspect that the immense power of the computer is being harnessed to this 'paper economy', not to do the same transactions more economically but to balloon the quantity and variety of financial exchanges. For this reason perhaps, high technology has so far yielded disappointing results in economy-wide productivity. I fear that, as Keynes seen even in his day, the advantage of the liquidity and negotiability of financial instruments come to the cost of facilitating nth-degree speculation which is short sighted and insufficient...I suspect that Keynes was right to suggest that we should provide greater deterrents to transient holdings of financial instruments and larger rewards for long-term investors" (cited in Foster, 2007). Tobin was making a point that the system was becoming inefficient by diverting increasing amounts of its surplus capital into casino-like and speculative activities, rather than long-term 
investment in the real economy to create employment and assist long-term economic stability. This means that financial expansion does not necessarily feed into a healthy real economy but rather leads towards stagnation, instability, and bubble and burst (Foster, 2007).

In the last thirty years, the economies of the world have undergone a profound transformation. Lapavitsas (2011:611-12), who noted with regards to financialisation: "as a systematic transformation of mature capitalist economies that comprises three fundamental elements: first, large non-financial corporations have reduced their reliance on bank loans and have acquired financial capacities; second, banks have expanded their mediating activities in financial markets as well as lending to households; third, households have become increasingly involved in the realm of finance both as debtors and as asset holders". All these studies have emphasised the fact that finance has become more dominant in the last thirty years or so, but the economic system remains capitalist (Wray, 2011).

We also find that after the 2008 global financial crisis led to the collapse of the credit system, the central bank had to rescue private banks. In the industrialised countries, the state came to the help of the market with the infusion of credit so that money credit could start again. In the post-war period, the Bank of England, for instance, played a central role in the functioning of the credit system by setting up interest rates. The state played a greater role in the regulation of the private financial system. However, with the adoption of neoliberalism in the developing countries in the 1980s, the private financial sector was accorded much greater freedom (Siddiqui, 2012). As a result, there was a sharp rise in shadow banking, i.e., the expansion of a parallel private monetary system. The collapse of Lehman in 2008 and other private monetary and financial institutions sent shock signals across the financial world. The crisis brought back the need for state intervention via central banks to bail out the economy and restore the credit system. (Brunhoff and Foley. 2007)

The advanced economies adopted "unconventional" monetary policies in response to the 2008 financial crisis. These included keeping interest rates extremely low to near zero and infusing huge amounts of liquidity into the economy with the hope of inducing investment and consumer demand. These policies were supposed to ensure recovery from recession. For instance, the US Federal Reserve adopted policies of "quantitative easing" through the purchase of Treasury Securities to the value of billions of US dollars. A similar policy was adopted by the European Central Bank (ECB) to spur economic growth through its acquisition of bonds starting in 2014 in response to continued slow growth. For example, by 2016, the ECB had accumulated assets of US\$ 4.9 trillion or about two-fifths of its GDP on its balance sheet (Kapeller, et al. 2018; Siddiqui, 2017a).

The quantitative easing policy was aimed to boost aggregate demand and ultimately to promote growth rates. The Federal Reserve embarked upon unprecedented purchase of longterm US Treasury debt obligations and private asset-backed securities. As a result, the inflated amount reached the US, which represented about one-quarter of the country's GDP. Moreover, the Federal Reserve was not alone, but Central Banks in the EU, Japan and the UK had also followed similar quantitative easing and monetary expansion policies, though of course at different levels. This, of course, influenced long-term interest rates in these individual countries. Short-term interest rates in the advanced economies were maintained for extended periods at almost zero (Shaikh, 2016; Beck et al., 2014). 
Critics have blamed 2008 financial crisis on deregulation of financial markets and financial innovation and according to them, such policies has encouraged risk-taking behaviour in the financial sectors, which created an unsustainable rise in private debt and asset bubbles (Siddiqui, 2017b). In fact, due to a number of reasons including a period of relative stability, the government supervisory authorities became less sensitive to the destructive potential and general instability associated with an increasingly complex financial system. This also coincided with the booming housing and urban property markets and increasing demand for high-yielding assets and high expectations on investments. These inherent weaknesses became more obvious when the housing bubble burst and housing prices fell sharply. As Kapeller, et al. 2018:310) argue: "growing inequality amplifies relative consumption concerns, which leads to a fall in saving rates and rising demands for credit. Following periods of relative financial stability, banks become increasingly willing to provide these loans, which cause a consumption boom. As private indebtedness increases and households reduce spending in order to serve debt payments, demand decreases, income stops rising, households become insolvent and the economy experiences a financial crisis."

Nine years have passed since the worst global financial crisis of 2008 occurred. All sorts of explanations have been presented for the cause of the crisis such as too little regulation and oversight, overly high levels of consumer debt, and rising inequalities which encouraged households to borrow to keep-up with high levels of spending, including bankers' greed and excess supply of global liquidity (Wray, 2011). Banks took the riskier assets to gamble in order to get higher returns. More risky innovations in terms of new products were seen as business success and a number of new marketing methods were used to attract new borrowers. Such developments gave increased importance to shadow banks and new branches of financial institutions that were not regulated as banks, as Wray (2011:9) notes: "over the past two or three decades there was increased "outsourcing," with pension, insurance, and sovereign wealth fund managers hiring Wall Street firms to manage firms. Firms like Goldman Sachs then carried out to the next logical steps, betting that the toxic waste they sold to clients would crater. And, as we now know, investment banks would help their clients hide debt through opaque financial instruments-building debts load far beyond what could be serviced-and then bet on the default of their clients through the use of credit default swaps (CDS). This is exactly what Goldman did to Greece."

\section{Conclusion}

The study found that a materialist analysis of monetary phenomena is crucial to fully understanding this issue including the financial crisis of 2008. This had been emphasised by Marx in terms of the primacy of production, which he called capitalist dynamics, as being deeply intertwined with money and finance. Marx pointed out the exploitation of labour within a monetary commodity-producing economy and its inherent tendency to move into crisis. Under capitalism, the value added in the production of a commodity has its exclusive source in "abstract labour", i.e., the living wage of workers. In the market, money is attached to a means of production inherited from the past. The value of labour power is exhibited in money wages, which is regulated by labour time required to reproduce the means of subsistence. He emphasised that surplus value is created from surplus labour, which is the difference between the labour spent in producing the product and the share of labour necessary for reproducing the necessary labour, i.e., wages. 
Marx analysed how surplus is distributed among various groups: interest to moneylenders/banks, rent to landlords and profits to merchants. He also says that when there is excessive speculation over the future distributions of surplus value then there is a possibility for great instability in the system. Such tendencies were clearly seen during the 2008 financial crisis.

The study finds that the theoretical weaknesses of the mainstream economists, whose analyses are based on the non-value approach, led to a failure to understand the historical background to the crisis. Mainstream economists are highly critical about the possibility of state borrowing or creating money, which is assumed to induce inflationary tendencies in the economy, yet the huge amount of credit diverted towards speculation in the name of banking innovations did not similarly attract their criticism. Certainly, such polices made some individuals very rich, but ultimately the state has to bear the losses in its role as a guarantor of the money system (Desai and Freeman, 2011).

This study is contributing to the understanding of money in capitalist economies including the financial crisis of 2008. The financial sector cannot grow independently of its base in the given productive system; therefore, bursting into bubbles was a recurrent and growing problem in the developed countries. Finally, increased financialisation will not remove stagnation and overproduction crises. Moreover, the growing financialisation prevalent in the world economy will result in greater penetration of foreign capital into developing countries, who are becoming increasingly dependent on foreign capital and technology (Siddiqui, 2015b). This is as witnessed over the last three decades or so with the pursuit of neoliberal globalization (Foster, 2007).

Keynes found money's macroeconomic impact, namely uncertainty, which he explains in universal terms. For Marx, the reason for uncertainty is associated with capitalist production decisions, which means capitalists are undertaking production for needs which are unknown to them; they are producing for other individuals not known to them. As a result, uncertainty arises because of the "social character of labour", meaning that whether the commodity satisfies needs or not is shown in monetary value outside the actual production.

\section{References}

- Arnon, A. 1984. "Marx Theory of Money: The Formative Years", History of Political Economy, 16 (4): 55-75.

- Beck, T; H. Degryseb; and C. Kneer. 2014. "Is More Finance Better? Distangling Intermediation and Size Effects of Financial System", Journal of Financial Stability, 10: 50-64.

- Brunhoff, S. de and D. Foley. 2007. "Karl Marx Theory of Money and Credit", A Handbook of Alternative Monetary Economics, in edited by P. Arestis and M. Sawyer, London: Edward Elgar, pp. 188-204.

- Campbell, M. 1997. "Marx and Keynes on Money", International Journal of Political Economy 27 (3): 65-91.

- Cartelier, J. 2007. "The Hypostasis of Money: An Economic Point of View", Cambridge Journal of Economics 31: 217-233. DOI: 101093/cje/bel022.

- Chick, V. 1992. On Money, Method and Keynes, Macmillan: Basingstoke.

- De Bolla, P. 1989. Discourse of the Sublime: Readings in History, Aesthetics, and the Subject, Oxford: Basil Blackwell. 
- Desai, R. and A. Freeman. 2011. "Value and Crisis Theory in the "Great Recession"”, World Review of Political Economy, 2 (1): 35-47.

- Eatwell, J. 1983. "The Analytical Foundations of Monetarism", in Keynes's Economics and the Theory of Value and Distribution, in edited by J. Eatwell and M. Milgate, 203-13, New York: Oxford University Press.

- Fine, B. 2011. "Financialization on the Rebound?" Memo, London: SOAS.

- Foley, D. 1986. Understanding Capital: Marx Economic Theory, Cambridge Massachusetts: Harvard University Press.

- Foster, J.B. 2007. “The Financialization of Capitalism”, Monthly Review, 58 (11): 114. https://monthlyreview.org/2007/04/01/the-financialization-of-capitalism/ (accessed on 6 January 2018).

- Galbraith, J.K. 1975. Money: Whence it came and where it Went, Penguin: London.

- Green, R. 1982. "Money, Output and Inflation in Classical Economics", Contribution to Political Economy 1: 59-85.

- Grieve, R.H. 2017, "Price Flexibility and Full Employment: Barking on the Wrong (Neoclassical) Tree", World Review of Political Economy, 8 (4): 480-502.

- Kaldor, N. 1982. The Scourge of Monetarism, New York: Oxford University Press.

- Kapeller, J., M.A. Landesmann, F.X. Mohr and B. Schutz. 2018. "Government Polices and Financial Crisis: Mitigation, Postponement or Prevention", Cambridge Journal of Economics, 42: 309-330. DOI: 10.1093/cje/beq073.

- Keynes, J.M. [1936] (1964). The General Theory of Employment, Interest, and Money, New York: Harcourt Brace Jovanovich.

- Lapavitsas, C. 2011. "Theorizing Financialization", Work Employment and Society, 25 (4): 611-26.

- Lapavitsas, C. 2009. "Financialized capitalism: Crisis and Financial Expropriation", Historical Materialism 17 (2): 114-48.

- Lawson, T. 2016. "Social Positioning and the Nature of Money", Cambridge Journal of Economics, 40 (4):961-96.

- Marx. K. [1867] 1976. Capital Volume I, London Penguin.

- Marx, K. [1885] 1978. Capital Volume II, London: Penguin.

- Marx, K. [1884] 1981. Capital Volume III, London: Penguin.

- Meek, R.L. 1973. Studies in the Labour Theory of Value, London: Lawrence and Wishart.

- Messori, M. 1997. "The Theory of Value without Commodity Money?" International Journal of Political Economy, 27 (2): 51-96, summer.

- Minsky, H.P. 1986. Stabilizing an Unstable Economy, New Heaven: Yale University Press.

- Patnaik, P. 2009. The Value of Money, New York: Columbia University Press.

- Peacock, M. S. 2017. "The Ontology of Money", Cambridge Journal of Economics 41: 1471-1487. doi: 10.1093/cje/bex012

- Robinson, J. 1956. The Accumulation of Capital, Philadelphia: Porcupine Press.

- Rowthorn, B. 1984. Capitalism, Conflict and Inflation: Essays in Political Economy, London: Lawrence and Wishart.

- Rowbotham, M. 1998. The Grip of Death: A Study of Modern Money, Debt Slavery and Destructive Economics, Oxford: John Carpenter Publishing. 
- Sawyer, M. 2001. "Kalecki on Imperfect Competition, Inflation and Money", Cambridge Journal of Economics, 25: 245-261.

- Sawyer, M. 2014. "What is Financialization?" International Journal of Political Economy, 42 (4): 5-18. Doi: 10.2753/IJP0891-19164201401.

- Searle, J.R. 2017. "Money: Ontology and Deception", Cambridge Journal of Economics 41: 1453-1470. doi:10.1093/cje/bex034

- Shaikh, A. 2016. Capitalism: Competition, Conflict, Crises, New York: Oxford University Press.

- Siddiqui, K. 2012. "Developing Countries' Experience with Neoliberalism and Globalisation", Research in Applied Economics, 4 (4): 12-37, December. DOI: $10.5296 /$ rae.v4i4.2878.

- Siddiqui, K. 2014. "Flows of Foreign Capital into Developing Countries: A Critical Review", Journal of International Business and Economics, 2 (1): 29-46, March.

- Siddiqui, K. 2015a. "Economic Policy Issues", Equilibrium Quarterly Journal of Economics and Economic Policy, 10 (1): 9-32. ISSN 1689-765X, e-ISSN 23533293.

- Siddiqui, K. 2015b. "Foreign Capital Investment into Developing Countries: Some Economic Policy Issues", Research in World Economy, 6 (2): 14-29. DOI:10.5430/rwe.v6n2p14

- Siddiqui, K. 2017a. "Austerity as a Tool of Fiscal Consolidation: Theoretical and Empirical Perspective", In edited by S. Owsiak, Public Finance and the New Economic Governance in the European Union, 116-66, Warsaw: Wydawnictwo Naukowe WN SA. ISBN 978-83-01-19812-1.

- Siddiqui, K. 2017b. "Financialization and Economic Policy: The Issues of Capital Control in the Developing Countries", World Review of Political Economy 8(4):564590, winter, Pluto Journals.

- Sweezy, P. M. 1994. "The Triumph of Financial Capital”, Monthly Review, 46 (2):112. https://monthlyreview.org/1994/06/01/the-triumph-of-financial-capital/. (accessed on 12 February 2018).

- Vasudevan, R. 2017. “The Significance of Marx's Theory of Money”, Economic and Political Weekly, LII (37): 70-82.

- Wray, L.R. 2011. “Minsky's Money Manager Capitalism and the Global Financial Crisis", International Journal of Political Economy, 40 (2): 5-20. 